\title{
Proximate Characteristics and Nutritional Value of White Anchovy Flour
}

\author{
Hendrayati $^{1}$, Theresia Dewi KB ${ }^{1}$, Laras Budyghifari ${ }^{2}$, Adriyani Adam ${ }^{1}$ \\ ${ }^{1}$ Lecturers of Department of Nutrition, Health Polytechnic Makassar, ${ }^{2}$ Lecturers of Food technology study program \\ student at Hasanuddin University Makassar
}

\begin{abstract}
Low fish consumption in some parts of Indonesia is caused by the high price of several types of fish. Its include types of fish that have a low social value in the community so it is less desirable although their value of nutrients is very good. Anchovy is actually the best source of calcium and protein. Calcium in white anchovy (Stolephorus $s p$ ) is very stable resistant and not easily soluble in water. White anchovies (Stolephorus sp) are excellent as a source of calcium and protein in children who are in their infancy, expectant mothers, nursing mothers and adult women to prevent osteoporosis. When the production volume of white anchovy (Stolephorus $s p$ ) is increased, making fish flour is a preservation method, It will make the benefits of anchovy can be maximised. White anchovy flour quality can be measured by proximate characteristics and nutritional quality. Proximate parameters in this study are determination of water content, ash content, peroxide numbers, acid numbers, and saponification numbers. Nutritional quality analysis such as carbohydrates, protein, fat, calcium, iron, fiber, zinc, DHA, EPA and trans fat. The characteristics of the proximate are good and meet the quality standards of a food product from fresh anchovy (Stolephorus $s p$ ) such as fiber content, ash content, number of peroxide and trans fatty acids. The best nutritional quality of fresh anchovy (Stolephorus sp) are the content of protein, calcium, iron ,zinc, DHA and EPA.
\end{abstract}

Keywords: Anchovy, Nutritional quality, Proximate characteristics and Stolephorus sp

\section{Introduction}

Indonesia is a country with excellent natural resources. Indonesia is an archipelago nation with number of waters wider than its land. It provides high production of marine products such as fish. The use of fish as a source of protein has not been optimally fulfilled. At the present time, protein intake is still dominated by vegetable protein about $68.3 \%$, while animal protein has only reached $31.7 \%$. The high intake of vegetable protein during growth has an unfavorable impact, considering the bioavailability of vegetable protein is very low. Animal protein is much better in supporting growth ${ }^{1}$.

Anchovy is consumed by the middle to lower classes so it is considered as type of fish that is not

\section{Corresponding Author :}

\section{Hendrayati}

hendrayati@poltekkes-mks.ac.id

081524005261 popular in the community. Anchovy is actually the best source of calcium that is resistant and does not dissolve easily in water. Anchovy is very good as a source of calcium in children who are growing up, pregnant women, nursing mothers and adult women to prevent osteoporosis ${ }^{1}$. Consumption of small fish provides benefits such as fish bones containing most minerals that can contribute significantly to reducing levels of micronutrients and protein malnutrition ${ }^{2}$. Abbey et $a l^{3}$ stated that consumption of small-sized fish species as a whole can contribute significantly to reducing the level of micronutrient and protein malnutrition.

When the production volume of white anchovy (Stolephorus $s p$ ) increases, the preservation method is needed, so that the benefits of anchovy can be maximized. One method of preserving fish is making fish flour. Fish flour is a dry solid product produced by removing most of the liquid and some or all of the fat contained in the body of the fish. Fish flour can be made from all types of 
fish, but only pelagic and demersal fish are widely used as raw materials for making fish flour. Anchovy is part of the demersal fish group ${ }^{4}$.

Fish flour has many benefits such as easy storage, can be processed into various food products, and has good nutritional value. The process of making anchovy fish into flour causes a change in the proximate characteristics of the product. Proximate analysis is the analysis of components of materials such as water, protein, fat, and ash (minerals) ${ }^{5}$. Analysis of these food components is interesting in the food industry for product development, quality control or regulatory objectives ${ }^{5,6}$. This study aims to determine the proximate characteristics and nutritional quality of anchovy flour (Stolephorus sp.)

\section{Materials and Method}

White anchovy fish flour (Stolephorus $s p$ ) was made in the food technology laboratory of the Department of Nutrition Poltekkes Kemenkes Makassar, fish flour production is refers to Alfianto with modification. White anchovy washed and their head and entrails are disposed. Headless fish and entrails are cleaned squeezed with gauze then soaked in lemon juice $0.2-0.3 \%$ for 1 hour, blended, squeezed with gauze, oven dried at $50^{\circ} \mathrm{C}$ for 8 hours, and sieved with 60 mesh size. Anchovy flour making is done in three replications.

Parameters in this study are determination of proximate characteristics such as water content, ash content, peroxide numbers, acid numbers, and saponification numbers. Nutritional quality analysis such as carbohydrates (Luff Schoroll), protein (Micro Kjedhal), fat (Soxhlet), calcium (Molumetri), iron (Spectrophotometry) and fiber (Crude Fiber) carried out in the Quality Control Laboratory at SMTI Makassar. Analysis of Zinc levels (18-13-1 / MU / SMM-SIG, ICP OES), DHA (18-6-1 / MU / SMM-SIG, GC), EPA (186-1 / MU / SMM-SIG , GC) and trans fat (18-6-1 / MU / SMM-SIG, GC) are carried out at the GIS Laboratory. PT. Saraswanti Indo Genetech Bogor, West Java.

\section{Results}

\section{Rendement}

White anchovy flour was made by obtained the right method to get the highest rendement. This research was conducted with three replications and the results are shown in Table 1.

Table 1. Rendement of White Anchovy Flour (Stolephorus sp)

\begin{tabular}{|l|l|l|l|l|}
\hline Replications & Fish weight (g) & Edible part weight (g) & Flour weight (g) & Rendement (\%) \\
\hline 1 & 5000 & 3750 & 653.25 & 17.42 \\
\hline 2 & 5000 & 3780 & 707.61 & 18.72 \\
\hline 3 & 5000 & 3765 & 717.60 & 19.06 \\
\hline
\end{tabular}

Source: Primary Data Research Results, 2019

Table 1 illustrate that the percentage of rendement in each replication of white anchovy flour (Stolephorus $s p$ ) is different. This is influenced by several factors, for example the treatment factor at the time of sifting. Sifting that carried out carefully resulting higher rendement of flour. The results of this study obtained a mean rendement of $18.40 \%$.

\section{Proximate Characteristic}

The results of the proximate characteristics on white anchovy flour (Stolephorus sp) shown in table 2. 
Table 2. Proximate Characteristics of White Anchovy Flour (Stolephorus sp)

\begin{tabular}{|l|l|l|l|l|l|l|l|}
\hline Sample & Fiber (mg) & $\begin{array}{l}\text { Water } \\
\text { content } \mathbf{( \% )}\end{array}$ & $\begin{array}{l}\text { Ash content } \\
\mathbf{( \% )}\end{array}$ & $\begin{array}{l}\text { Peroxide } \\
\text { number (mEq) }\end{array}$ & $\begin{array}{l}\text { Acid number } \\
\mathbf{( \% )}\end{array}$ & $\begin{array}{l}\text { Saponification } \\
\text { number (mg/g) }\end{array}$ & $\begin{array}{l}\text { Trans fatty } \\
\text { acid }\end{array}$ \\
\hline 1 & 60.91 & 6.70 & 7.78 & 59.39 & 73.66 & 129.93 & Not detected \\
\hline 2 & 60.90 & 6.06 & 7.74 & 59.23 & 73.57 & 126.83 & Not detected \\
\hline Mean & 60.91 & 6.38 & 7.76 & 59.31 & 73.62 & 126.88 & Not detected \\
\hline
\end{tabular}

Source: Primary Data Research Results, 2019

Table 2 gives an overview of the results of the proximate analysis in duplicate for each indicator. The result shows that trans fatty acid is not detected, this shows that the content of trans fatty acids in fresh white anchovy flour (Stolephorus $s p$ ) was below the minimum limit of the method used $<0.02$. White anchovy flour (Stolephorus $s p$ ) can be said have no trans fatty acids or hydrogenated fats.

\section{Nutritional quality}

This study also carried out analysis of good macronutrients such as carbohydrates, proteins, fats and micronutrients including iron, calcium and zinc. The results can be seen in Table 3.

Table 3. Nutrient content of fresh white anchovy flour (Stolephorus sp)

\begin{tabular}{|l|l|l|l|l|l|l|}
\hline Sample & Carbohydrate (g) & Protein (g) & Fat (g) & Iron (mg) & Calcium (mg) & Zinc (mg) \\
\hline 1 & 5.73 & 82.967 & 6.04 & 5.817 & 503 & 6.56 \\
\hline 2 & 5.72 & 82.963 & 6.04 & 5.815 & 505 & 6.56 \\
\hline Mean & 5.73 & 82.965 & 6.04 & 5.816 & 504 & 6.56 \\
\hline
\end{tabular}

Source: Primary Data Research Results, 2019

Table 3 shows that the protein content of white anchovy flour (Stolephorus sp), is very high. Protein content mean valued $82.965 \%$ that means each $100 \mathrm{~g}$ of flour contains 82.965 gram of protein. In addition, white anchovy flour also contains high calcium which reach $504 \mathrm{mg}$ for every $100 \mathrm{~g}$ of flour.

\section{DHA and EPA}

DHA and EPA are essential fatty acids, especially for children who are growing up. White anchovy flour (Stolephorus sp) is also analyzed for DHA and EPA content. The results of the analysis can be seen in Table 4.

Table 4. The content of essential fatty acids in white anchovy flour (Stolephorus sp)

\begin{tabular}{|l|l|l|}
\hline Sample & DHA $(\mathbf{m g})$ & EPA $(\mathbf{m g})$ \\
\hline 1 & 826.7 & 382.7 \\
\hline 2 & 826.7 & 382.7 \\
\hline Mean & 826.7 & 382.7 \\
\hline
\end{tabular}


Source: Primary Data Research Results, 2019

The results of DHA and EPA (essential fatty acids) from white anchovy flour (Stolephorus $s p$ ) in sequence are $826.7 \mathrm{mg}$ and $382.7 \mathrm{mg}$ in every $100 \mathrm{~g}$.

\section{Discussion}

\section{Rendement}

Rendement analysis in a flour product aims to determine the weight of flour produced from a number of raw materials used. In this study, the ratio between white anchovy flour (Stolephorus $s p$ ) produced from fresh white anchovy flour (Stolephorus $s p$ ) was measured. The average yield of rendement reached $18.40 \%$. These results indicate that from $1000 \mathrm{~g}$ the weight of fresh anchovy (Stolephorus $s p$ ) produces 184 $\mathrm{g}$ of fresh white anchovy flour (Stolephorus $s p$ ). The results of this analysis are lower than the catfish head rendement by $26.97 \%$ and higher than the body flesh of catfish by $15.70 \%$. This research only use edible part of fish (without head and entrails). The greater bone mass will result in a higher flour rendement ${ }^{8}$.

\section{Proximate Characteristic}

Proximate analysis can also provide a reference to the standard substances that must be present in a food product. In addition, proximate analysis can be used to evaluate and develop better food product formulas and evaluate existing food products so that other food ingredients can be added to produce better food products (In this research, proximate analysis includes crude fiber content, water content, ash content, peroxide numbers, acid numbers, saponification numbers, and trans fatty acids ${ }^{9}$.

Analysis of fiber content of white anchovy flour (Stolephorus sp) showed an average of $60.91 \mathrm{mg}$. This shows that in $100 \mathrm{~g}$ of white anchovy flour (Stolephorus $s p$ ) contains $6.09 \mathrm{~g}$ fiber. This fiber content shows a fairly high level from fish species. Fiber is more commonly found in plants or vegetables and fruits. If the fiber requirement of 1-3 years children is $10 \mathrm{~g}$ (Nutritional Adequacy Rate, 2013), then fiber from $100 \mathrm{~g}$ of white anchovy flour (Stolephorus $s p$ ) can meet $60 \%$ of their needs. The usage of this fiber must be supported by sufficient fluid consumption, where the average fiber in fish is $70 \%$ water soluble ${ }^{10}$.

Acid number is a measure of the amount of free fatty acids, the molecular weight of acids. Acid numbers are expressed as the number of milligrams of $\mathrm{KOH}$ used to neutralize free fatty acids found in 1 gram of oil or fat. A large acid number indicates a large free fatty acid, derived from oil or fat hydrolysis because of poor food processing. The higher value the acid number indicate lower quality of food products. The results of this study showed the levels of acid from fresh anchovy (Stolephorus $s p$ ) reached $73.62 \%$. Fish flour production should be carried out by oven drying using low temperature below $50^{\circ} \mathrm{C}$ to reduce their acid number. The higher the acid number, the lower the quality of a food product ${ }^{11}$.

Trans fatty acids are a type of fat that is not good for health. This fat is classified as a type of unsaturated fat. Trans fatty acids are hydrogenated fats. Hydrogenation is a process of adding hydrogen molecules to a substance. The role and function of trans fat in the body can be obtained at the end of the hydrogenation process which can cause disruption of body function at the cellular level. The results of the analysis of trans fatty acid in white anchovy flour (Stolephorus $s p$ ) stated no detectability. This shows that the content of trans fatty acids in this flour is declared safe ${ }^{12}$.

\section{Nutritional quality}

Carbohydrate analysis results show that white anchovy flour (Stolephorus $s p$ ) contains $5.73 \mathrm{~g}$ carbohydrate from $100 \mathrm{~g}$ total ingredients. If we look at the role of carbohydrates as an energy contributor, $100 \mathrm{~g}$ of fish flour will produce $22.92 \mathrm{Kcal}$ of energy or fulfill $3-4 \%$ of the needs of 11 -month-old children as complementary foods for breast milk (MP-ASI). This fulfillment is not a problem considering that white anchovy flour (Stolephorus $s p$ ) is basically intended for protein sources ${ }^{13}$.

The results of protein analysis on white anchovy flour (Stolephorus $s p$ ) showed an average of 82,965 g. This shows a high protein content that $100 \mathrm{~g}$ fish flour containing 82,965 $\mathrm{g}$ of protein. The protein content of fish has high quality because fish contain complete amino acids and excellent digestive quality. If the protein needs of 4-6 years children are $40 \mathrm{~g}, 50 \mathrm{~g}$ white anchovy flour (Stolephorus $s p$ ) is enough to fulfill daily protein needs ${ }^{14}$. 
The result shows that white anchovy flour (Stolephorus $s p$ ) in average contains $6.03 \mathrm{~g}$ of fat. This shows that in $100 \mathrm{~g}$ white anchovy flour (Stolephorus $\mathrm{sp}$ ) only contains $6.03 \mathrm{~g}$ fat. Low-fat foods are very necessary in the current era, where changes in activity and eating patterns trigger the emergence of degenerative diseases. The fat content of white anchovy flour (Stolephorus $s p$ ) only contributes energy by $54.27 \mathrm{Kcal} / 100$ g product. Low fat content and high protein is food elements that is needed in children who are growing up to avoid obesity $^{15-20}$.

\section{DHA and EPA}

The results of the analysis of DHA content in white anchovy flour (Stolephorus sp) in $100 \mathrm{~g}$ contain an average of $826.67 \mathrm{mg}$. The DHA content of white anchovy flour (Stolephorus $s p$ is very high so it is appropriate if given to children in the form of complementary foods for breast milk MP-ASI ${ }^{16}$.

EPA analysis results on white anchovy flour (Stolephorus sp) in average shows $382.7 \mathrm{mg} . / 100 \mathrm{~g}$ of flour. The high EPA content in this product shows that the quality of the fatty acids in this product is quite good. However, to maximize the use of EPA and DHA other nutrients needed are Vitamin $C$, Vitamin $B_{6}$, Vitamin $\mathrm{B}_{3}$, Zinc, and Magnesium. Because in the process of fatty acid metabolism, especially the conversion of Alpha Linoleic Acid (ALA) to DHA and EPA requires these nutrients. DHA and EPA intake directly from food is very good, but their source is quite expensive. White anchovy flour (Stolephorus $s p$ ) is an alternative to fulfill both of these nutrients, in addition to being cheap and easy to obtain ${ }^{17}$.

\section{Conclusion}

Rendement of white anchovy flour (Stolephorus $s p$ ) made from their edible parts reaches $18.40 \%$. This flour have good proximate characteristics and fiber, ash content, peroxide numbers, and trans fatty acids meet the quality standards of a food product from white anchovy flour (Stolephorus $s p$ ). Proximate characteristics that do not meet the quality standards of food products from white anchovy flour (Stolephorus $s p$ ) are acid numbers and saponification numbers. The best nutritional quality of white anchovy flour (Stolephorus $s p$ ) is the content of protein, calcium, iron and zinc. The content of carbohydrates and fats can contribute energy of 22.92 Kcal and $54.27 \mathrm{Kcal}$ in every $100 \mathrm{~g}$ of white anchovy flour (Stolephorus $s p$ ). Nutritional quality of essential fatty acids (DHA and EPA) is very high, so it can be used as an alternative to fulfilling the intake of both essential fatty acids that are cheap and easily obtained. The process of making white anchovy flour (Stolephorus $s p$ ) can be implemented in the industry with advanced technology or carried out by domestic industry with simple technology.

Ethical Clearance- Taken from University ethical committee

\section{Source of Funding- Self \\ Conflict of Interest - Nil \\ References}

1. Almatsier S. Basic Principles of Nutrition. Jakarta: PT. Gramedia Pustaka Utama. 2010.

2. Setiawati, Ervinia, Fitriani. Dissemination of Anchovy as a Food Material Containing High Calcium Sources. Bogor; Bogor Agricultural Institute. 2009.

3. Toppe J. The Nutritional Benefits of Fish are Unique. Eurofish Magazine, Issue 2014. ; 3/2014.

4. Afrianto E, and Evi L. 2005. Fish Feed. Yogyakarta: Kanisius.

5. Akther S, Islam MB, Habibur R, and Abdus SB. 2018. Proximate Composition and Nutritional Value of Fish Powder Composition (FPC) from Different Dried SIS Fishes in Bangladesh. Research Journal of Food Science and Nutrition 3: 9-14.

6. Trugo LC. offee. Analysis of Coffee Products. Encyclopedia of Food Sciences and Nutrition 2003. ;2(2): 1498-1506. https://doi.org/10.1016/B0-12227055-X/00271-6.

7. Amitha CV, Raju LP, Lakshmisha P, Arun KA, Sarojini, Gajendra and Jag P. Nutritional Composition of Fish Bone Powder Extracted from Three different Fish Filleting Waste Boiling with Water and an Alkaline Media. Int.J.Curr.Microbiol. App.Sci 2019. ; 8(2): 2942-2948.

8. Pratiwi F. Utilization of Flying Meat Flour for Making Fish Sticks. Thesis. Department of Service and Production Technology Semarang State University. 2013. 
9. Darsudi. Proximate Content Analysis of Raw Materials and Artificial Feeds / Pellets for Mangrove Crabs (Scylla paramamosain). Bul. Tek Lit. Akuakultur 2008. ; 7(1).

10. Ariani, Mewa dkk. Variety of Animal Food Consumption by Region and Income at the Household Level. Agriculture Policy Analysis 2018. ; 1(2): 147-163.

11. Hastuti. Qualitative and Quantitative Analysis of Formaldehyde in Salted Fish in Madura. Agrointek Journal. 2010.; Vol 4

12. Pujiati. Arneliwati, and Siti R. Relationship between Eating Behavior and Nutritional Status in Adolescent Girls. JOM 2015. ; 2(2),

13. Rachmawati, Abdul H, and Andriani. Utilization of Anchovy (Stolephorus sp) in the MP-ASI Formula. Nasuwakes Scientific Health Journal 2014. ; 7(2): $147-155$.

14. Fatmawati and Mardiana. Snakehead Fish Flour as a Source of Protein (Food Supplement). Bionature Journal 2014. ; 15(1): 54-60.
15. Kurniawan MY, Dodik B, and Rezzy EC. Body Perception and Eating Disorders in Adolescents. Indonesian Clinical Nutrition Journal 11(3).

16. Sulaeman A. 2013. Riskesdas 2013 Data Search. Bogor; Bogor Agricultural Institute. 2015.

17. Fivi MD. Omega 3: Study of Literature. Journal of Public Health 2012. ; 6(2): 113-117.

18. Endah Yani, R.W., Mallongi, A., Andarini, S., Prijatmoko, D., Dewanti, I.R. The effect of zinc saliva on the toddlers nutritional status, Journal of International Dental and Medical Research, vol: 9, issue : 1, 2016-01-01

19. Masriadi, Azis, R., Sumantri, E., Mallongi, A. Effectiveness of non pharmacologic therapy through surveillance approach to blood pressure degradation in primary hypertension patients, Indonesia. Indian Journal of Public Health Research and Development. vol: 9, issue : 4, 2018-04-01

20. Owildan Wisudawan B, et al. Bioaerosol pollution in intensive-care unit of Dr. Wahidin Sudirohusodo Hospital Makassar: Morning and midday assessment. Enferm Clin. 2020. https://doi. org/10.1016/j.enfcli.2020.02.009 